\title{
GAMBARAN TINGKAT SENSITIFITAS TELAPAK TANGAN PADA PEKERJA SALON KECANTIKAN DI KOTA MANADO
}

\author{
${ }^{1}$ Trinny M.C.A Solangs \\ ${ }^{2}$ D. Pangemanan \\ ${ }^{2}$ Hedison Polii
}

\author{
${ }^{1}$ Kandidat Skripsi Fakultas Kedokteran Universitas Sam Ratulangi Manado \\ ${ }^{2}$ Bagian Fisiologi Fakultas Kedokteran Universitas Sam Ratulangi Manado \\ Email: trinnysolangs@yahoo.com
}

\begin{abstract}
In this study the sensitivity level of difference in getting on palms beauty salon workers between the age groups of adolescents with adult age groups. However, the results of this study obtained data the different levels of sensitivity palms beauty salon workers in both age groups rernaja and adult age groups, in which the adolescent age group level of sensitivity on the palm of his hand is higher than in the adult age group, so that the research This nosiseptor at salon workers in the teenage years with the number amounted to 23 workers and nosiseptor percentnya by as much as $45 \%$. Although the level of sensitivity on the palm of the hand is different beauty salon workers. Manifestations of chemical workers exposed to the beauty parlor palms and age, but at the age of adolescents with a higher sensitivity rate than adult rare cause. Therefore, teenage beauty salon worker with a high sensitivity palms generally have long contaminated chemicals. To measure the level of sensitivity on the palm of beauty salon worker, used a seal test trials and the results confirmed by frequency tables. Because the cost of a cheap and practical and beauty salon area which is along the road Malalayang
\end{abstract}

Keyword: sensitivity, nosiseptor.

\begin{abstract}
Abstrak: Dalam penelitian ini di dapatkan perbedaan tingkat sensitivitas pada telapak tangan pekerja salon kecantikan antara kelompok yang usia remaja dengan kelompok yang usia dewasa. Namun pada hasil penelitian ini diperoleh data adanya perbedaan tingkat sensitivitas telapak tangan pekerja salon kecantikan baik pada kelompok yang usia rernaja maupun kelompok yang usia dewasa, dimana pada kelompok usia remaja tingkat sensitivitas pada telapak tangannya lebih tinggi dibanding pada kelompok yang usia dewasa, sehingga pada penelitian ini nosiseptor pada pekerja salon pada usia remaja dengan banyaknya nosiseptor berjumlah 23 pekerja dan menurut percentnya sebanyak 45\%. Oleh karena itu pekerja salon kecantikan usia remaja dengan sensitivitas telapak tangan yang tinggi umumnya belum lama terkontaminasi bahan kimia. Tidak dilakukan pemeriksaan laboratorium untuk mengetahui penyebab perbedaaan tingkat sensitifitas pada pekerja salon kecantikan tersebut. Untuk mengukur tingkat sensitivitas pada telapak tangan pekerja salon kecantikan, digunakan uji test stempel dan hasil dikonfirmasikan dengan tabel frekwensi. Karena biaya yang murah dan praktis dan area salon kecantikan yang berada di sepanjang jalan malalayang.
\end{abstract}

Kata Kunci: sensivitas, nosiseptor. 
Banyak para ahli berpendapat bahwa tingkat sensitivitas kulit tiap individu berbanding lurus dengan jumlah nosiseptor. International Association for the Study of Sensitivity (Tahun 1979) mendefinisikan sensitivitas sebagai "suatu pengalaman sensorik dan emosional, yang berkaitan dengan kerusakan-kerusakan jaringan yang nyata atau berpotensial untuk menimbulkan kerusakan jaringan yang lain. Secara klinis, sensitivitas adalah suatu rangsangan yang diterima reseptor yang dihantar ke hipothalamus. ${ }^{1}$

Pada daerah kulit, ada yang dinamakan reseptor syaraf yang bekerja secara khusus, dan hanya akan menerima rangsangan tertentu. Reseptor dapat dikelompokkan berdasarkan struktur, lokasi sumber rangsang serta jenis atau sifat rangsangan yang dapat diterima oleh reseptor. Nosiseptor (reseptor nyeri). ${ }^{2}$

Rangsangan yang diterima dari luar dan kerusakan jaringan misalnya akibat bahan kimia, tusukan atau terbakar. Ujung saraf bebas merupakan ujung saraf aferen (sensorik) yang membawa informasi dari tubuh ke otak. Fungsi ujung saraf bebas ini yakni untuk mendeteksi rangsangan sensitivitas. $^{3}$

Berdasarkan uraian di atas, maka pada penelitian ini bertujuan untuk mengetahui gambaran tingkat sensitivitas telapak tangan pada pekerja salon kecantikan di Kota Manado.

\section{METODE}

Jenis penelitian ini adalah ekspedisi modul lapangan dengan pendekatan cross sectional study. Tempat penelitian di salonsalon kecantikan di Kota Manado yang dilakukan selama bulan September 2010 sampai dengan bulan Februari 2011. Sampel adalah sebagian dari populasi yang memenuhi kriteria inklusi yang berada di Kota Manado antara lain; Pekerja salon kecantikan wanita, usia 17-45 tahun, lama bekerja di salon kecantikan minimal enam bulan, tidak sakit pada saat penelitian dan bersedia mengikuti penelitian. Variabel penelitian berupa tingkat sensitivitas telapak tangan dan pekerja sa-lon kecantikan. Instrumen penelitian antara lain; Cap 6x8, kuisoner, jarum pentul dan bantal cap.

\section{Cara Kerja}

Responden duduk di kursi dengan mata tertutup. Membatasi daerah di tengahtengah telapak tangan kiri dengan stempel. Stempelkan pula dikertas laporan orang yang mencatat hasil pengamatan. Pemeriksa (P) memeriksa letak reseptor nyeri di dalam daerah yang telah dibatasi tadi dengan cara menusukkan jarum, mulai dari kotak kecil kiri atas ke kanan sampai diujungnya, lalu di baris kotak kecil berikut dan seterusnya. Bila merasa nyeri subjek peneliti mengangkat jari tangan kanannya sebagai syarat. Pemeriksa mencatat hasil pengamatannya di kertas laporan.

\section{Analisa Data}

Data yang terkumpul dianalisis dengan cara mentabulasinya, kemudian dibuatkan tabel-tabel distribusi frekuensi.

\section{HASIL}

Pada penelitian ini didapatkan 50 orang responden yang memenuhi persyaratan kriteria inklusi.

\section{Deskripsi Responden Salon Kecantikan}

\section{Berdasarkan umur}

Tabel 1. Distribusi responden berdasarkan umur.

\begin{tabular}{lcc}
\hline Umur (tahun) & n & \% \\
\hline $\mathbf{1 7 - 2 0}$ & 20 & 50 \\
$\mathbf{2 1 - 2 3}$ & 10 & 15 \\
$\mathbf{2 4 - 3 4}$ & 15 & 25 \\
$\mathbf{3 5 - 4 5}$ & 5 & 10 \\
\hline
\end{tabular}

Berdasarkan tampilan pada Tabel 1 diperlihatkan jumlah responden sebanyak 50 orang remaja yang berusia 17-20 tahun (50\%), sedangkan umur 35-45 tahun merupakan angka terkecil, yaitu lima orang. 


\section{Berdasarkan pendidikan terakhir}

Tabel 2. Distribusi responden berdasarkan pendidikan terakhir.

\begin{tabular}{lll}
\hline Pendidikan & $\mathbf{N}$ & $\mathbf{\%}$ \\
\hline SLTP & 5 & $15 \%$ \\
SMA & 35 & $65 \%$ \\
Univ/Akademi & 10 & $20 \%$ \\
\hline Jumlah & 50 & $100 \%$ \\
\hline
\end{tabular}

Berdasarkan data responden pada tabel 2 terlihat pekerja menurut pendidikan terakhir di SLTP sebanyak lima orang dan yang menyelesaikan sekolah di bangku SMA sebanyak 35 orang dan pada pekerja yang menyelesaikan studi di bangku Kuliah terdapat sepuluh orang.

Berdasarkan tabel responden tabel 3 didapatkan lamanya responden bekerja yang paling dominan adalah 6-10 bulan. Karena seiring waktu, pasti ada pertukaran akibat rentannya usia seseorang ataupun ada kendala lain.

\section{Berdasarkan masa kerja}

Tabel 3. Distribusi responden berdasarkan masa kerja

\begin{tabular}{lcc}
\hline $\begin{array}{l}\text { Masa Kerja } \\
\text { (bulan) }\end{array}$ & $\mathbf{N}$ & $\mathbf{\%}$ \\
\hline $1-5$ & 0 & 0 \\
$6-10$ & 20 & $60 \%$ \\
$>10-12$ & 15 & $25 \%$ \\
$>12-15$ & 10 & $15 \%$ \\
$>15-\ldots$ & 5 & $10 \%$ \\
\hline Jumlah & 50 & $100 \%$ \\
\hline
\end{tabular}

\section{Distribusi responden berdasarkan jumlah nosiseptor di telapak tangan}

Tabel 4. Distribusi responden berdasarkan jumlah nosiseptor telapak tangan.

\begin{tabular}{lcc}
\hline Nosiseptor & N & \% \\
\hline $\mathbf{4 - 7}$ & 15 & 25 \\
$\mathbf{8}-\mathbf{1 1}$ & 6 & 15 \\
$\mathbf{1 2}-\mathbf{1 4}$ & 5 & 10 \\
$\mathbf{1 5}-\mathbf{1 9}$ & 23 & 45 \\
$>\mathbf{2 0}-\ldots$ & 1 & 5 \\
\hline Jumlah & 50 & 100 \\
\hline
\end{tabular}

Berdasarkan data responden pada tabel 4 terlihat bahwa nosiseptor pekerja berjumlah 15-19 sebanyak 23 orang. Dan itu berjumlah lebih ba-nyak dari pada pekerja dibandingkan pada 12-14 jumlah nosiseptor pada lima orang pekerja yang hanya di dapatkan $10 \%$ banyaknya.

\section{BAHASAN}

Dalam penelitian ini di dapatkan perbedaan tingkat sensitivitas pada telapak tangan pekerja salon kecantikan antara kelompok yang usia remaja dengan kelompok yang usia dewasa. Namun pada hasil penelitian ini diperoleh data adanya perbedaan tingkat sensitivitas telapak tangan pekerja salon kecantikan baik pada kelompok yang usia rernaja maupun kelompok yang usia dewasa, dimana pada kelompok usia remaja tingkat sensitivitas pada telapak tangannya lebih tinggi dibanding pada kelompok yang usia dewasa, sehingga pada penelitian ini nosiseptor pada pekerja salon pada usia remaja dengan banyaknya nosiseptor berjumlah 23 pekerja dan menurut persennya sebanyak $45 \%$.

Pada penelitian ini kami tidak mengamati efek fisiologis yang diakibatkan oleh bahan kimia yang terpapar pada telapak tangan pekerja salon kecantikan tersebut secara detail. Seringnya telapak tangan pekerja salon kecantikan terkontaminasi dengan zat-zat kimia berbahaya yang ada pada alat-alat kosmetika dapat menyebabkan menurunnya tingkat sensitifitas telapak tangan pada kelompok pekerja salon kecantikan usia dewasa/reproduktif. Sebagai tambahan, dari data sekunder didapati 95\% subyek berjenis kelamin wanita, walaupun hasilnya tidak dianalisa tetapi nampaknya hal ini memerlukan kontribusi pada hasil studi ini.

Besar sampel dan wawancara singkat yang diambil pada penelitian ini secara random, lima salon kecantikan. Dengan demikian hasil yang diperoleh tidak bisa digeneralisasikan. Oleh karena itu dibutuhkan penelitian lebih lanjut dengan besar sampel yang lebih banyak, waktu yang lebih lama (longitudinal studi), dan mem- 
bandingkan pengaruh berbagai jenis salon terhadap penurunan sensitivitas pada telapak tangan pekerja salon.

\section{DAFTAR PUSTAKA}

1. Lawley T, Lawley KB. Fisiologi Nyeri. In: Asdie AH, editor. Harrison PrinsipPrinsip Ilmu Penyakit Dalam Volume 1. Jakarta: EGC, 1995.
2. Dewoto HR. Nyeri pada system musculoskeletal. Dalam: Harahap M, editor. Ilmu Penyakit Kulit. Jakarta; Hipokrates, 2000.

3. Wasitaatmadja SM. Nyeri Akut. Dalam: Djuanda A, editor. Ilmu Penyakit Kulit (Edisi Keenam). Jakarta: Fakultas Kedokteran Universitas Indonesia, 2010. 